\title{
Analisis Penerapan Gerakan Membaca Bersama di SDN Wonolopo 02 Semarang
}

\author{
Garda Perkasha* \\ PGSD Fakultas Ilmu Pendidikan Universitas PGRI Semarang
}

\begin{abstract}
Abstrak
Analisis Penerapan Gerakan Membaca Bersama di SDN Wonolopo 02 Semarang. Tujuan Penelitian ini untuk menganalisis dan mendeskripsikan kegiatan membaca bersama di SDN Wonolopo 02 Semarang. Jenis penelitian yang digunakan

Kata Kunci:

Analisis, Membaca

Bersama, SDN

Wonolopo 02 yaitu deskriptif kualitatif. Metode pengumpulan data penelitian ini melalui observasi,wawancara, angket, dan dokumentasi. Subyek yang di ambil dalam penelitian ini yakni SDN Wonolopo 02 Semarang dengan sampel yang diambil dari populasi yang benar-benar representatif (mewakili) atau guru sudah memilih 5 siswa kelas rendah dan kelas tinggi untuk mewakali di SDN Wonolopo 02 Semarang. Hasil penelitian menunjukan bahwa berdasarkan hasil observasi, wawancara dan angket pelaksanaan gerakan membaca bersama pada tahapan awal sudah sangat baik dengan rata-rata skor $100 \%$. Pada aspek sarana dan prasarana mencapai prosentase 100\% respon positif. Sedangkan tahapan pembiasaan diperoleh hasil $90 \%$. Sebagai optimalisasi minat baca 100\% siswa di SDN Wonolopo 02 Mijen sudah memilih buku yang disukai dalam pelaksanaan kegiatan membaca bersama.Dapat disimpulkan bahwa pelaksaan kegaitan membaca bersama di SDN Wonolopo 02 Mijen sudah berjalan baik.
\end{abstract}

\begin{abstract}
The purpose of this study was to analyze and describe the activities of reading together at SDN Wonolopo 02 Semarang. The type of research used is descriptive qualitative. This research data collection method through observation, interviews, questionnaires, and documentation. Subjects taken in this study are SDN Wonolopo 02 Semarang with samples taken from a truly representative population (representing) or the teacher has chosen 5 low and high class students to represent at SDN Wonolopo 02 Semarang. The results showed that based on the results of observations, interviews and questionnaires the implementation of joint reading movements in the initial stages was very good with an average score of $100 \%$. In the aspect of facilities and infrastructure reached a percentage of $100 \%$ positive responses. While the stages of habituation obtained $90 \%$ results. As an optimization of reading interest $100 \%$ of students at SDN Wonolopo 02 Mijen have chosen a book that is preferred in the implementation of joint reading activities. It can be concluded that the implementation of joint reading activities at SDN Wonolopo 02 Mijen has been going well.

\section{Keywords: \\ Analysis, Reading \\ Wonolopo 02}

Together, SDN
\end{abstract}

\footnotetext{
* Corresponding author.

E-mail Addresses: Kirimpesanmu.keasha@gmail.com (Garda Perkasha)
} 


\section{PENDAHULUAN}

Pendidikan anak memang sangat penting. Menurut peneliti pendidikan dari sekolah akan membantu seseorang bukan hanya mengerti dari mata pelajaran yang diajarkan, namun yang terpenting yaitu cara belajar yang terstruktur dan baik. Sistem pendidikan nasional UU No. 20 tahun 2003 Bab VI pasal 17 ayat 1 menyebutkan bahwa "Pendidikan dasar merupakan jenjang pendidikan yang melandasi jenjang pendidikan menengah". Isi UU tersebut berarti bahwa pendidikan di sekolah dasar merupakan jenjang pendidikan yang sangat penting dan menentukan karena pendidikan di sekolah dasar merupakan landasan pertama untuk menanamkan suatu konsep yang benar kepada anak. Konsep pendidikan yang dianut di negara kita adalah konsep pendidikan sepanjang hayat. Hal ini sejalan dengan kewajiban setiap manusia untuk selalu belajar sejak dilahirkan sampai akhir hayatnya. Suatu masyarakat yang maju dapat di tunjang dengan budaya membaca. Segala pengetahuan yang di peroleh tidak mungin didapat tanpa membaca karena budaya membaca perlu dikembangkan sejak dini serta membaca berperan penting dalam kehidupan

Menurut Patiung 92016) Membaca merupakan suatu kegiatanatau proses kognitif yang berupaya untuk menemukan berbagai informasi yang terdapat dalam tulisan. Hal ini berarti membaca merupakan proses berfikir untuk memahami isi teks yang dibaca. Oleh sebab itu, membaca bukan hanya sekadar melihat kumpulan huruf yang telah membentuk kata, kelompok kata, kalimat, paragraf, dan wacana saja, tetapi lebih dari itu bahwa membaca merupakan kegitan memahami dan menginterpretasikan lambang atau tanda atau tulisan yang bermakna sehingga pesan yang disampaikan Meurut Wulanjani (2019) Membaca merupakan salah satu hal yang penting dalam segala macam proses pembelajaran. Melalui membacalah berbagai ilmu pengetahuan, yang dapat mengantarkan pada kesuksesan, bisa kita dapatkan. Membaca merupakan kegiatan atau bagian dari literasi.Program literasi disekolah yaitu kegiatan yang dilakukan sebelum pembelajaran dimulai. Permendikbud nomor 23 tahun 2015 telah menyadari pentingnya penumbuhan karakter peserta didik melalui kebijakan membaca selama 15 menit sebelum memulai pembelajaran. Membaca 15 menit sebelum kegiatan pembelajaran (kegiatan literasi) dapat membangun peseta didik agar lebih giat untuk membaca.

Keterampilan yang dimiliki seseorang dari kegiatan berpikir, berbicara, membaca, dan menulis. Berdasarkan uraian di atas maka dapat dinyatakan bahwa literasi adalah (1) kemampuan baca tulis atau kemelekwacaan (2) kemampuan mengintegrasi antara menyimak,berbicara, membaca, menulis dan Kementrian pendidikan dan kebudayaan melalui peraturan menteri Nomor 23 Tahun 2013 merencanakan sebuah gerakan literasi sekolah untuk membantu siswa dalam menumbuhkan budaya, membaca dan menulis di lingkungan sekolah.

Sasaran utama gerakan literasi sekolah yaitu di sekolah dasar. Peserta didik sekolah dasar masih mudah untuk dikembangkan dalam usia 6-12 tahun. Oleh karena itu pihak sekolah harus mengadakan program Gerakan Literasi sekolah sebagai upaya untuk meningkatkan minat baca peserta didik dengan cara mengembangkan pengelolaan perpustakaan sekolah. Dalam pelaksanaan program Gerakan Literasi Sekolah. Dalam pelaksanaan program Gerakan Literasi Sekolah ini dapat dilihat dari kedisiplinan siswa, Gerakan Literasi Sekolah dasar dilaksanakan dalam tiga tahap yaitu tahap pembiasan, tahap pengembangan, dan tahap pembelajaran. Tahap pembiasan bertujuan untuk menumbuhkan minat peserta didik tahap bacaan dan kegiatan membaca. (1) Tahap pembiasaan ini kegiatan yang dilakukan sesuai dengan jenjang pendidikan yaitu SD kelas rendah dan SD tinggi, dengan kegiatan seperti ini menyimak dan membaca buku bacaan/pengayaan. (2) Tahap pengembangan bertujuan untuk mempertahankan minat terhadap bacaan dan terhadap kegiatan membaca, serta ,meningkatkan kelancaran dan pemahaman membaca peserta didik. Kegiatan yang dilakukan meliputi menyimak, membaca, berbicara, menulis dan memilih informasi. (3) Tahap pembelajaran bertujuan untuk mempertahankan minat peserta didik terhadapan bacaan dan terhadap kegiatan membaca, serta meningkatkan kecakapan literasi peserta didik melalui buku-buku pengayaan dan buku teks pelajaran.

Menurut Suwardi (2017:90) Literasi adalah "mastery of, or fluent control over, a secondary discourse." dalam memberikan pengertian demikian Gee menggunakan dasar pemikiran bahwa literasi merupakan suatu berpikir (3) kemampuan siap untuk di gunakan dalam menguasai gagasan baru atau cara mempelajarinya (4) piranti kemampuan sebagai penunjang keberhasilannya dalam lingkungan akademik atau sosial (5) kemampuan performasi membaca dan menulis yang selalu di perlukan (6) kompetensi seorang akademisi dalam memahami wacana secara profesional.

Berdasarkan wawancara dengan Ibu Senjani S.Pd. Dan Ibu Titi Lestari S.Pd selaku guru kelas di SDN Wonolopo 02 Semarang kegiatan Literasi khusus membaca bersama mulai dilakukan secara rutin 15 menit sebelum pembelajaran dimulai. Dari sebelumnya belum dilakukan secara rutin, kini kegiatan tersebut telah dilakukan secara aktif setiap pagi. Dan hal ini memiliki banyak pengaruh terhadap siswa. 
Berdasarkan uraian latar belakang di atas, maka peneliti perlu melakukan penelitian yang berjudul "Analsiis Penerapan Gerakan Membaca Bersama di SDN Wonolopo 02 Semarang"

Tujuan penulisan artikel ini adalah untuk menganalisis dan mendeskripsikan kegiatan membaca bersama di SDN Wonolopo 02 Semarang

Menurut Laila (2016:3) Gerakan Literasi Sekolah (GLS) merupkan sebuah upaya yang dilakukan secara menyeluruh untuk menjadikan sekolah sebagai organisasi pemebajaran yang warganya literat sepanjang hayat melalui pelibatan publik.Sekolah sebagai organisasi pembalajaranyang warganya literat adalah sekolah yang menyenangkan dan ramah anak, terlihat dari semua warga menunjukkan empati, kepedulian, semangat ingin tau dan sinta pengetahuan, cekap berkomunikasi dan dapat berkontribusi kepada lingkungan sosialnya.

Pembelajaran bersifat multilterasi sebagai implemtasi kurikulum 2013 mengcakup kegiatan :"(a) literasi sebagai rangkaian kecakapan membaca, menulis, berbicara, kecakapan berhitung, dan kecakapan dalam mengakses dan menggunakan informasi; (b) literasi sebagai praktik sosial yang penerapannya dipengaruhi oleh konteks; (c) literasi sebagai proses pembelajaran dengan kegiatan membaca dan menulis sebagai medium untuk merenungkan, menyelidik, menanyakan, dan mengkritisi ilmu dan gagasan yang dipelajari, (d) literasi sebagai teks yang bervariasi menurut subjek, genre, dan tingkat kompleksitas bahasa."(Kemendibud:2018).

Berdasarkan pengertian Gerakan Literasi Sekolah para ahli dapat disimpulkan bahwa Gerakan Literasi Sekolah (GLS) adalah gerakan sosial dengan dukungan berbagai pihak untuk pembiasaan membaca peserta didik yang dilakukan dengan 15 menit membaca buku sebelum jam pembelajaran berlangsung dan ketika pembiasaan membaca terbentuk, maka diarahkan pada tahap pengembangan dan pembelajaran.

Menurut Yunus (2018:1) literasi merupakan sebagai kemampuan untuk menggunakan bahasa dan gambar dalam bentuk yang kaya dan beragam untuk membaca, menulis, mendengarkan, berbicara, melihat menyajikan, dan berfikir kritis tentang ide-ide. Hal ini memungkinkan untuk berbagi informasi, berinteraksi dengan orang lain. Pentingnya literasi untuk siswa adalah menuntut kesadaran siswa akan pentingnya literasi. Keterampilan literasi yang baik akan membuka jalan kepada keterampilan berbahasa lainnya, seperti menyimak, berbicara dan menulis. Menurut Sari (2017) Literasi adalah kemampuan berbahasa seseorang (menyimak, berbicara, membaca, dan menulis) untuk berkomunikasi dengan cara yang berbeda sesuai dengan tujuannya.

Kegiatan literasi memiliki beberapa dua tujuan. Yang pertama tujuan umum yakni menumbuhkan karakter gemar membaca melalui kegiatan literasi. Dan yang ekdua tujuan khusus yakni Menumbuhkan budaya literasi dan menjadikan sekolah sebagai tempat atau taman belajar yang menyenangkan dan ramah agar warga sekolah mampu mengelola pengetahuan dengan baik.

Menurut Tarigan (2010:5) membaca adalah suatu proses yang dilakukan serta dipergunakan oleh pembaca untuk memperoleh pesan yang hendak disamapaikan oleh penulis melaui media katakata/bahasa tulis. Dalam hal ini, membaca adalah suatu usaha untuk menelurusi makna yang ada dalam tulisan. Sedangkan menurut Dalman (2013:7) "membaca dalah proses perubahan bentuk lambang/tanda/tulisan yang bermakna. Oleh sebab itu, kegiatan membaca ditentukan fisik dan mental yang menuntut sesorang untuk mengingtepretasikan imbol-simbol tulisan. Dengan aktif dan kritis sebagai pola komunikasi dengan diri sendiri, agar pembaca dapat menemukan makna tulisan dan memperoleh informasi.

Berdasarkan pengertian membaca menurut para ahli diatas dapat disimpulkan bahwa membaca merupakan suatu kegiatan atau proses kognitif yang berupaya untuk menemukan berbagai informasi yang terdapat dalam tulisan. Hal ini berarti membaca adalah proses berpikir untuk memahami teks. Oleh karena itu membaca bukan hanya melihat kumpulan huruf yang membentuk kata, kalimat, paragraf, dan wacana, melainkan membaca merupakan kegiatan memmahami tulisan yang bermakna sehingga pesan yang dismapaikan penulis dapat diterima pembaca.

Menurut Dr.Thamrin kasman, Drs.Wowon widaryat, Dr.Supriono dalam Buku Panduan Gerakan Literasi Sekolah (2016:8) menyatakan prinsip-prinsip Kegiatan membaca sebagai berikut: 1) Buku yang dibaca / dibacakan adalah buku bacaan, bukan buku teks pelajaran. 2) Buku yang dibaca / dibacakan adalah buku yang diminati oleh peserta didik. Peserta didik diperkenankan membaca buku yang dibawa dari rumah. 3)Kegiatan membaca / membacakan buku di tahap pembiasaan ini tidak di ikuti oleh tugastugas menghafalkan cerita, menulis sinopsis, dan lain-lain. 4)Kegiatan membaca/membacakan buku di tahap pembiasaan ini dapat di ikuti dengan diskusi informal tentang buku yang dibaca atau dibacakan, atau kegiatan yang menyenangkan terkait buku yang dibacakan apabila waktu memungkinkan. Tanggapan dalam diskusi dan kegiatan lanjutan ini tidak di nilai atau di evaluasi.5) Kegiatan membaca / membacakan buku ditahap pembiasaan ini berlangsung dalam suasana yang santai dan menyenangkan. 
Guru menyapa perserta didik dan bercerita sebelum membaca buku dan meminta mereka untuk membaca buku.

\section{METODE PENELITIAN}

Menurut Moleong metode penelitian kualitatif yaitu penelitian atau inkuiruralistik atau alamiah, etnografi, interaksionis simbolik, perspektif ke dalam, etnometodologi, the chicago school, fenomenologis, studi kasus, interpretatif, ekologis, dan deskriptif (Bogdan dan Biklen, 1982:3). Penelitian kualitatif adalah penelitian yang menghasilkan prosedur analisis yang tidak menggunakaan prosedur analisis statistik atau cara kualifikasi lainnya. Penelitian kualitatif didasarkan pada upaya membangun pandangan mereka yang diteliti yang rinci, dibentuk dengan kata-kata, gambaran holitik dan rumit.

Lokasi penelitian ini adalah di SDN Wonolopo 02 Semarang yang terletak di desa Wonolopo SDN Wonolopo 02 Semarang dalam Pelaksanaan Gerakan Membaca Bersama

Dalam penelitian ini, sumber data kata-kata dan tindakan diperoleh melalui wawancara secara langsung kepada kepala sekolah, guru, dan siswa di sekolah dasar kecamatan mijen kota semarang, sedangkan melalui dokumentasi saat pelaksanaan kegiatan gerakan membaca bersama di Sekolah Dasar Negeri Wonolopo 02 Mijen Kota Semarang.

Menurut Djam'an Satori, Aan komariah (2017:44-47) konsep subjek penelitian dengan apa atau siapa yang diteliti. Sedangkan darimana data itu diperoleh disebut unit observasi atau unit pengamatan. Dalam penelitian mengambil subyek yang diambil dari SD N Wonolopo 02 dengan sampel yang diambil dari populasi yang benar benar representative (mewakili), atau guru sudah memilih siswa kelas rendah dan kelas tinggi untuk mewakili. Sampel merupakan representative dari populasi yang menggambarkan keseluruhan populasi.

Proses seleksi yang dimaksud disini adalah proses untuk mendapatkan orang, situasi, kegiatan / aktivitas, dokumentasi yang diperoleh dari sejumlah orang yang dapat mengungkapkannya atau dokumen yang banyak lalu dipilih berdasarkan tujuan yang ingin dicapai.

Dalam penelitian kualitatif, uang menjadi instrumen atau alat penelitian adalah peneliti itu sendiri. Oleh karena itu peneliti sebagai instrumen juga harus "divalidasi" sebagai jauh peneliti kualitatif melakukan penelitian yang selanjutnya terjun ke lapangan. Instrumen pengumpulan data harus sesuai dalam bentuk kata-kata dan penguasaan teori wawasan terhadap bidang yang diteliti, serta kesiapan dan bekal masuk lapangan.

Dalam penelitian ini, data yang diteliti berupa data rekaman, tertulis,wawancara, dokumentasi. Untuk mendapatkan data diperlukan alat bantu berupa daftar pertanyaan dan alat perekam. Daftar pertanyan yang digunakan berisi pertanyaan-pertanyaan yang digunakan dalam wawancara, pada tahap wawancara pertanyaan diperlihatkan kepada responden saat pelaksanaan wawancara. Kemudian hasil wawancara yang telah direkam ditraskipsikan peneliti untuk membantu dalam analisis data.

Metode pengumpulan data yang digunakan dalam penelitian analisis gerakan membaca bersama iniadalah sebagai berikut.

Pada saat observasi peneliti ikut terlibat langsung dalam kegiatan membaca bersama. Dalam penelitian ini peneliti menggunakan metode nonpartisipatif, peneliti hanya bertindak sebagai pengamat saat guru dan siswa sedang mengadakan kegiatan literasi di SDN Wonolopo 02 Semarang, berdasarkan hasil observasi peneliti akan menguraikan hasil observasi kedalam bentuk kata-kata.

Wawancara peneliti melakukan wawancara dengan bertatap muka secara langsung dan secara individual. Dalam penelitian ini peneliti melakukan wawanca kepada Kepala Sekolah, guru, dan beberapa siswa, tempat pada saat wawancara berbeda-beda. Kegiatan wawancara kepada Kepala Sekolah dilakukan di ruang tamu sekolah, wawancara pada guru dilakukan di ruang guru, dan wawancara pada siswa dilakukan pada saat jam istirahat yaitu di perpustakaan sekolah.

Kuisioner pada penelitian ini ditujukan kepada kepala sekolah, guru kelas, dan juga siswa kelas III dan kelas V SD N Wonolopo 02 Mijen.

Teknik dokumentasi yang digunakan dalam penelitian ini, mengumpulkan data berupa sumber tulis, gambar (fot), film, dan karya-karya monumental pada hasil kegiatan pelaksanaan gerakan membca bersama di SD N Wonolopo 02 Mijen Semarang. Dokumentasi yang diambil oleh peneliti berupa video pelaksanaan gerakan membaca bersama, foto, buku-buku literasi, profil sekolah di SD N Wonolopo 02 Mijen Semarang.

Keabsahan data Uji kredibilitas data atau kepercayaan terhadap data hasil penelitian kualitatif antara lain dilakukan dengan melakukan validasi hasil penelitian dengan dosen ahli.

Triangulasi sumber peneliti perlu melakukan eksplorasi untuk mengecek kebenaran data dari beragam sumber. Untuk meguji kredibilitas data tentang pelaksanaan Gerakan Membaca Bersama pada siswa SDN Wonolopo 02 Mijen, maka pengumpulan data dan pengujiannya dilakukan kepala sekolah, 
guru,dan siswa. Data dari tiga sumber data tersebut dideskripsikan, dikategorikan, mana padangan yang sama, dan spesifik dari tiga sumber data tersebut

Menguji kredebilitas data dengan trianggulasi teknik yaitu mengecek data kepada sumber yang sama teknik yang berbeda. Data aktifitas siswa dalam pelaksanaa Gerakan Membaca Bersama di SDN Wonolopo 02 Mijen. Dalam penelitian ini menggunakan

\section{ANALISIS DAN PEMBAHASAN}

Tahap pertama yaitu melakukan studi pendahuluan melalui observasi, wawancara dan angket terhadap guru kelas V SDN Wonolopo 02 Mijen tujuannya untuk menemukan permasalahan terkait dengan latar belakang yang di ambil oleh peneliti. Permasalahan yang ditemukan, selanjutnya dianalisis berdasarkan pengamatan dan penilitian yang telah dilakukan. Hasil analisis kemudian digunakan peneliti untuk perancangan penelitian.

Tahap selanjutnya yaitu melakukan penelitian dengan melakukan pengamatan secara langsung gerakan membaca bersama di SDN Wonolopo 02 Semarang.

Berdasarkan hasil penelitian dan pembahasan pelaksanaan Gerakan Literasi Sekolah pada tahapan awal sudah sangat baik dengan rata-rata skor $100 \%$. Pada aspek sarana dan prasarana mencapai prosentase $100 \%$ respon positif. Sedangkan tahapan pembiasaan sudah baik hanya saja pada indikator ada tim literasi sekolah yang berkerjasama dengan eleman publik tidak ada sama sekali, sehingga hanya menunjukan prosentase $90 \%$. Faktor pendukung lainnya juga berperan penuh misalkan melibatkan orang tua dan publik masyarakat dalam pengadaan kegiatan literasi tersebut. Hanya saja sekolah tidak melibatkan publik alumni dalam mengembangkan kegiatan gerakan membaca bersama.

Untuk membantu guru dalam pelaksanaan Gerakan Membaca Bersama, banyak sekali sarana dan prasarana yang harus dioptimalkan.Menurut Yunus Abidin, Tita Mulya, Hana Yunansah (2017:289296)Sarana dan prasarana sekolah adalah modal dasar keempat bagi terciptanya sekolah literasi.Sarana dan prasanan ini berkenaan dengan bahan ajar (teks), perpustakaan, pojok baca, pusat literasi, serta sarana dan prasanan yang terakitnya dengan budaya literasi di sekolah. Berkenan dengan bahan ajar, bahan ajar yang hendaknya tersedia adalah bahan ajar yang dikembangkan guru berbasis kemampuan motivasi, dan minat siswa, dengan kata lain sekolahnya tidak bergantung pada bahan ajar yang dibeli, namun sebaliknya guru dan kepala sekolah harus merancang program khusus bagi pengemabangan bahan ajar literasi secara mandiri.

Pengembangan sarana literasi khususnya kegiatan membaca bersama membutuhkan sumber daya yang memadai.Partisipasi publik seperti komite sekolah, orang tua, alumi dapat membantu memilihara dan mengembangkan sarana agar capaian literasi dapat ditingkatkan. Ketika pihak sekolah melibatkan publik dalam pelaksanaan GLS, maka ekosistem sekolah akan menjadi terbuka dan sekolah mendapatkan kepercayaan yang semakin baik dari orang tua dan elemen masyarakat lain.

Berdasarkan hasil penelitian dan pembahasan dalam pelaksanaan Gerakan Literasi Sekolah sebagai optimalisasi minat baca siswa di peroleh adanya $100 \%$ siswa di SDN Wonolopo 02 Mijen sudah memilih buku yang disukai dalam pelaksanaan kegiatan membaca bersama. Di sekolah yang saya teliti sudah mempunyai pojok baca atau perpustakan yang dapat meningkat giat membaca. Penghambat dari optimalisasi minat baca siswa yaitu guru ikut serta orang tua dalam membiaskan anak membaca buku sebelum tidur dengan prosentase $58,3 \%$ kurang begitu optimal dalam pencapaian minat baca anak.

\section{KESIMPULAN}

Berdasarkan penelitian yang telah dilaksanakan, simpulan yang dapat peneliti berikan pada penelitian dan analsiis gerakan membaca bersama di SDN Wonolopo 02 Semarang adalah sebagai berikut : Berdasarkan hasil penelitian dan pembahasan pelaksanaan Gerakan Literasi Sekolah pada tahapan awal sudah sangat baik dengan rata-rata skor $100 \%$. Pada poin pelaksanaan Gerakan Literasi Sekolah sebagai optimalisasi minat baca siswa di peroleh adanya 100\% siswa di SDN Wonolopo 02 Mijen sudah memilih buku yang disukai dalam pelaksanaan kegiatan membaca bersama.Dari hasil wawancara yang di peroleh peneliti dari nara sumber dapat disimpulkan pula bahwa saran dan prasana dalam kegiatan membaca bersama ini sudah memadai. Khususnya buku sebagai saran pokok dalam pelaksanaan gerakan membaca bersama. 


\section{DAFTAR PUSTAKA}

Abidin,Yunus,dkk. 2018. Pembelajaran Literasi Strategi Meningkatkan Kemampuan Literasi Matematika, Sains, Membaca dan Menulis. Jakarta:Bumi Aksara.

Dalman. 2013. Keterampilan Membaca. Bandung: Raja Grafika Persada.

Darmiatun, Suyatri. 2013. Implementasi Pendidikan Karakter Di Sekolah. Yogyakarta:Gavemedia.

Endraswara,Suwardi.2017.Literasi Sastra:Teori,Model, dan Terapan.Yogyakarta:morfalingua.

Fajarini, Ulfah. 2014. Peranan Kearifan Lokal Dalam Pendidikan Karakter. Jurnal Penamas. Universitas Islam Negeri Syarif Hidayahtullah Jakarta.

Faradina, Nindya. 2017. Pengaruh Program Gerakan Literasi Sekolah Terhadap Minat Baca Siswa Di SD Islam Terpadu Muhamadiah An-Najah Jatinom Klaten.Jurnal Hanata Widya. Universitas Negeri Yogyakarta.

Gunawan, Imam. 2014. Metodelogi Penelitian. Jakarta : Bumi Aksara.

H.G. Tarigan. 2008. Membaca Sebagai Suatu Keterampilan Berbahasa. Bandung: Bumi Aksara.

Moleong Lexy J., 2017.Metodelogi Penelitian Kualitatif. Bandung:PT Remaja Rosdakarya.

Patiung, Dahlia. 2016. Membaca Sebagai Sumber Pengembangan Intelektual . Jurnal Hukum Pidana dan Ketatanegaraan, Volume 5 Nomor 2, Halaman 352-376. Tersedia Pada: http://journal.uinalauddin.ac.id/index.php/al_daulah/article/view/4854.

Priyatni, Tri dan Endah., 2010. Membaca Sastra Dengan Ancangan Literasi Kritis.Jakarta:Sinar Grafika Offset.

Rahmawati Laila. (2016). Sosialisai Implementasi Gerakan Literasi Sekolah. http://id.uinantasari.ac.id/7594/1/Sosialisai implemtansi Gerakan Literasi Sekolah.Pdf110 April 2019 ,(21:30)

Retno, Wulandari (2017). Implemnetasi Gerakan Literasi Sekolah (GLS) di SMP Negeri 5 Malang. http://karya-ilmiah.um.ac.id/index.php/sastra-indonesia/article/view/58628 . 10 April 2019 ,(21:55)

Sareb Putra, R. Masri. 2008 . Menumbuhkan Minat Baca Sejak Dini. Jakarta : PT Macanan Jaya Cemerlang.

Sari, Esti Swatika dan Setyawan Pujiono. 2017. Budaya Literasi di Kalangan Mahasiswa FBS UNY. Litera, Volume 16, Nomor 1, Halaman 105-113. Tersedia Pada: https://journal.uny.ac.id/index.php/litera/article/viewFile/14254/9441

Satori,Dr.Djam'an Satori dan Komariah, Aan. 2017. Metodologi Penelitian Kulitatif. Bandung: Alfabeta.

Toharun,Uus,dkk. 2011.Membangun Literasi Sains Peserta Didik. Bandung:Anggota IKAPI.

Wulanjani, Arum Nisma, Candradewi Wahyu Anggraeni. 2019. Meningkatkan Minat Membaca melalui Gerakan Literasi Membaca bagi Siswa Sekolah Dasar. Proceeding of Biology Education, Volime 3 Nomor 1 Halaman 26-31. Tersedia http://journal.unj.ac.id/unj/index.php/pbe/article/download/12305/7374. 